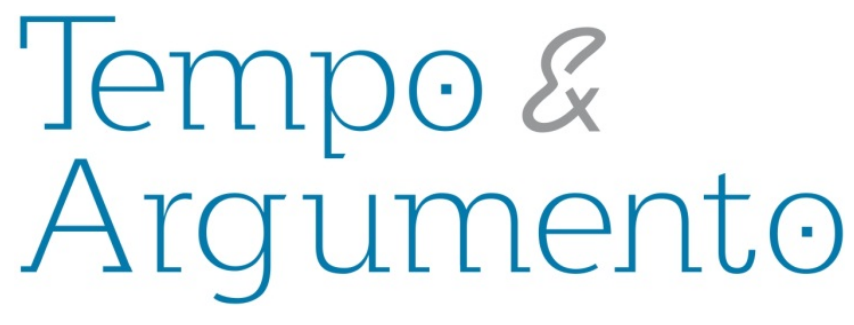

\title{
As redes políticas de solidariedade na América Latina ${ }^{1}$
}

\begin{abstract}
Resumo
A pesquisa que ampara este artigo teve como foco investigar os graus de relações políticas estabelecidas entre o movimento revolucionário brasileiro e o exterior em países que tanto favoreceram a luta de brasileiros, como serviram de acolhimento aos exilados. A solidificação destes acordos ocorreu no bojo de um contexto explosivo de transformação social, dando origem a grupos que substituíram os conflitos armados tradicionais do passado por estruturas políticas paralelas e difusas que estiveram na emergência de uma variedade de movimentos de resistência armada existentes na América Latina, África e Europa.
\end{abstract}

Palavras-chave: Ditadura e Ditadores - América Latina, Exilio - América Latina, Movimentos Sociais.

\author{
Maria Cláudia Badan Ribeiro \\ Doutora em História Social pela Universidade \\ de São Paulo - USP. Estágio Pós-Doutoral pelo \\ Instituto de Altos Estudos da América Latina \\ (IHEAL/Sorbonne Nouvelle). Pesquisadora \\ Colaboradora junto ao Departamento de \\ Sociologia da Universidade Estadual de \\ Campinas (IFCH/UNICAMP). \\ Brasil \\ mariaclaudia.badanribeiro@gmail.com
}

\section{Para citar este artigo:}

RIBEIRO, Maria Cláudia Badan. As redes políticas de solidariedade na América Latina. Revista Tempo e Argumento, Florianópolis, v. 8, n. 17, p. 311 - 349. jan./abr. 2016.

DOI: $10.5965 / 2175180308172016311$

http://dx.doi.org/10.5965/2175180308172016311

\footnotetext{
${ }^{1}$ Este texto é resultado de um ano de pesquisa de Pós-doutorado realizada junto ao Instituto de Altos Estudos da América Latina (IHEAL/Sorbonne) com o apoio da Coordenação de Aperfeiçoamento de Pessoal de Nível Superior (CAPES). Processo $n^{\circ}$ 9593-11-0. A investigação teve continuidade junto ao Departamento de Sociologia da Universidade Estadual de Campinas (IFCH/Unicamp).
} 


\title{
The political solidarity networks in Latin America
}

\begin{abstract}
Our research focuses on investigating the degree of political relationship between the Brazilian revolutionary movement and others countries that have favored the struggle of Brazilian exiles. The solidification of these agreements occurred in the midst of an explosive context of social transformation giving rise to groups that replaced the traditional armed conflicts by the construction of parallel and diffuse groups present in the emergence of a variety of revolutionary movements in Latin America, Africa and Europe.
\end{abstract}

Keywords: Dictatorship and Dictators - Latin America, Exile - Latin America, Social Movements.

\section{Introdução}

Este texto pretende apresentar as redes de solidariedade revolucionárias que existiram no exterior durante o regime militar brasileiro, quando pessoas ou grupos estabeleceram laços de cooperação e ajuda em países da América Latina, Europa e África. Nossa preocupação foi a de mostrar de que forma essas redes se inseriram na resistência à ditadura, em que consistiu essa solidariedade e quais acordos políticos elas originaram.

É importante destacar que o conceito de solidariedade foi empregado aqui como parte de uma cultura política de uma época e também dentro das relações de poder vigentes. Sabemos que a noção de solidariedade é permeada de ambiguidades e que suas manifestações ou mudanças de sentido ocorreram de acordo com as dinâmicas históricas.

Uma rápida consulta ao dicionário nos ajuda a definir a palavra solidariedade, tanto como um gesto individual quanto coletivo. Solidariedade poder ser definida como um laço ou ligação mútua entre duas ou mais pessoas, como o sentimento de simpatia, ternura ou piedade para com os pobres e injustiçados ou como assistência moral oferecida às pessoas em momentos difíceis. Pode ser também entendida como uma 
sociólogos no passado e que, em sua vertente cristã, mantém relação com a ideia de fraternidade e de amor ao próximo, e com uma forma de justiça pautada em concepções religiosas (WEBER, 1999, p. 44-84).

Distante das práticas sociais caritativas ou benevolentes, o termo solidariedade adquiriu diferentes sentidos ao longo da História e em consonância com a compreensão do que era sociabilidade. A solidariedade aparece no passado como uma solidariedade cívica, no seu aspecto contratual de acordo entre cidadãos e Estado na garantia de direitos civis, direito à vida, à propriedade, à justiça e à liberdade de pensamento e movimento. Está expressa como base iluminista, tendo sido também evocada na Revolução Francesa como parte de um ideal universalista.

Somente um século mais tarde é que o termo se inscreve num campo de disputa, quando a palavra solidariedade adquire nos séculos XIX e XX sentido de solidariedade política, sendo uma reivindicação da classe operária, de grupos sociais que encarnam juntos a luta contra um Estado opressor, denunciando sua natureza burguesa e seu caráter de árbitro das desigualdades (MARX, 1991, p. 50). O termo solidariedade passa então a ter novos contornos, identificando-se com a luta de classes, com a progressiva divisão social do trabalho (DURKHEIM, 1999) e inscrevendo-se na ideia de emancipação política e social (e não apenas civil) a partir de experiências comuns partilhadas entre grupos, associações e partidos políticos. O termo solidariedade passa então a se manifestar como identificação coletiva de doutrinas e interesses, apoiado na ideia de uma comum situação de exploração e de injustiça².

Se a solidariedade no passado se apresentava como um instrumento de acesso à res publica, neste trabalho ela aparece como um gesto individual ou coletivo, de transformação da sociedade, como parte de uma oposição política feita por forças revolucionárias num contexto de opressão, como foram as ditaduras civis-militares na América Latina.

\footnotetext{
${ }^{2}$ Cf. ZOLL, Rainer. E Depois vieram os trabalhadores e a solidariedade trabalhadora. In ZOLL, Rainer. $\mathbf{O}$ que
} é solidariedade hoje? ljuí: Editora ljuí, 2007, p. 55-82. 
A linha mestra deste trabalho consiste em mostrar qual foi a dimensão internacional da luta brasileira, suas relações estruturais e operacionais no exterior a partir de um enfoque que ultrapasse a simples sobrevivência física dos protagonistas ou aspectos ligados particularmente ao trauma e ao sentimento de estar exilado. Quisemos mostrar até que ponto e de que modo o projeto político radical sobreviveu.

A presente pesquisa dialoga com outras produções acadêmicas sobre o exílio político, mas pretende indicar também novas formas de abordagem, indicando novas fontes, temáticas e estudos específicos sobre o assunto que levem em consideração a construção de estruturas políticas paralelas, difusas ou exteriores ao corpo tradicional do Partido, da Igreja, dos Sindicatos e que estiveram na origem da emergência de uma variedade de movimentos revolucionários que existiram naqueles anos. Se estas estruturas em sua liberdade de movimento não deixaram de estabelecer laços com os mecanismos tradicionais, souberam, por outro lado, denunciar seu esgotamento diante de períodos de francas mudanças históricas.

Cabe ressaltar aqui que as forças de esquerda também não eram homogêneas, e a colaboração fornecida aos militantes políticos no Brasil e no exterior atravessou atitudes também ambivalentes, pois a disposição em ajudar dependeu também de questões simplesmente de temperamento, de interesse intelectual, de questões familiares ou de generalizações que afirmavam a necessidade de "proteger as vítimas da violência" para além de uma clara linha política adotada. Os acordos de cooperação foram realizados de maneira não oficial, dependendo, para existir, do mais completo sigilo.

Usamos o termo solidariedade neste texto como uma categoria heurística para pensar um conjunto diferente de experiências e comportamentos sociais, mas ao mesmo tempo como expressão de uma sociabilidade marcada pela oposição, estritamente política ou não, mas que dependeu essencialmente de uma escolha e de um compromisso.

O trabalho de campo para esta pesquisa concentrou-se em entrevistas realizadas no Brasil e no exterior que tiveram como objetivo elucidar tanto a atuação política de brasileiros exilados, como entrar em contato com remanescentes da Rede Solidariedade 
de Henri Curiel na França. Guiamo-nos, para a elaboração das questões, pela história oral temática, utilizando perguntas dirigidas aos entrevistados, que se dispuseram a fornecer informações sigilosas de sua atuação naqueles anos. Inexistem pesquisas feitas no Brasil que contribuam para pensar e para mostrar atividades intergrupos, a solidificação de acordos sigilosos, com destaque para redes informais ou frentes revolucionárias ou conspirativas. Portanto, o ineditismo desta pesquisa sugeriu a leitura de ampla bibliografia sobre exílio político brasileiro e a consulta a documentos nacionais e internacionais (quando existiam). As entrevistas foram, portanto, primordiais no desvendamento e compreensão da lógica de atuação clandestina da luta armada e dos laços forjados com outros grupos de esquerda ${ }^{3}$.

\section{A Rede franco-argelina Solidariedade}

Como parte da luta anticolonialista surgiu em Paris um grupo chamado Solidariedade. Fundado em 1962 por ex-combatentes da Guerra da Argélia, tendo na figura de Henri Curiel seu principal líder e criador, a ideia da Rede Solidariedade surgiu de um acordo estabelecido entre Henri Curiel e Ben Barka, militante marroquino, chefe do movimento terceiro-mundista e pan-africano ${ }^{4}$. Financiada pelos argelinos, em especial

\footnotetext{
${ }^{3}$ Algumas entrevistas tiveram duração de duas horas em média enquanto outras se estenderam por alguns dias, realizadas presencialmente ou através de esclarecimentos via mensagem eletrônica. As gravações foram realizadas em sua grande maioria na residência dos entrevistados. Outras questões foram respondidas por mensagem eletrônica, através de envio de roteiro específico. Além da coleta de dados por entrevistas, foi realizada ampla consulta a arquivos públicos brasileiros e estrangeiros, sistematizando estes conhecimentos. A saber, Arquivo Edgard Leuenroth (AEL/UNICAMP) Centro de Documentação e Memória da UNESP (CEDEM), Arquivo Público do Estado de São Paulo (DEOPS), Arquivo Público do Rio de Janeiro (APERJ), Arquivos do Ministério do Interior francês (Fontainebleau), Biblioteca François Mitterand (BNF), Biblioteca de Documentação Internacional Contemporânea (BDICNanterre), Centro LEBRET-IRFED, Instituto Ibero Americano (IAI Berlim) e Arquivos da STASI alemã, graças à ajuda atenciosa da Sra. Gerlinde Schade. Por delimitação de espaço, nem todas estas fontes foram incorporadas ao texto.

${ }^{4}$ A partir de 1964 começou a se organizar a Conferência Tricontinental, prevista para ocorrer no ano seguinte em Cuba. Ben Barka era o grande líder desta Conferência, tendo sido designado seu presidente. Foi a Rede Solidariedade que, em contato com a América Latina, Ihe forneceu as informações para o convite oficial aos dirigentes do continente. Seu sequestro e desaparecimento no ano de 1965 na Brasserie Lipp em Paris foram realizados, como veio a se comprovar posteriormente, pelos serviços secretos americanos, com a cumplicidade da polícia marroquina e do SDECE francês (Os serviços secretos franceses). (PERRAULT, 1984, p. 132 e p. 135).
} 
durante o governo argelino de Ben Bella 5 , e tendo como base principal de suas atividades as cidades de Argel e Paris, a Rede funcionava em duas frentes: uma legal, de contornos caritativos e ligada a atividades de socorro emergencial junto a refugiados, e outra completamente clandestina.

A Rede não tinha posições políticas definidas, mas se apresentava como uma central de ajuda aos movimentos de libertação no mundo. O próprio Henri Curiel tinha suas origens no Terceiro Mundo e conhecia de perto a miséria de seu povo egípcio (PERRAULT, 1984, p. 91).

O ecletismo de Solidariedade pode estar na origem de sua longa existência, que se calcula em dezesseis anos de atuação até o assassinato de Henri Curiel, em $1978^{6}$. Como afirmou uma de suas integrantes, a genialidade de Henri Curiel foi a de reunir pessoas que vinham de horizontes políticos diferentes, mas que podiam ajudar os "mais fracos". Como Curiel afirmava, "aqueles que combatem merecem ser ajudados" (ROGALSKI, 1998, p. 163).

No entanto, esta solidariedade internacional, que encontrou sua expressão mais clara em figuras como Henri Curiel, Mehdi Ben Barka ou Ernesto Che Guevara, não representou, um ato de caridade indiferenciada, mas um apoio a forças que agiram movidas por ideais revolucionários. A estrutura de Solidariedade era diferente da máquina pesada dos partidos, em especial do Partido Comunista, mesmo que Curiel se assumisse como um comunista ortodoxo e fosse um entusiasta do governo russo ${ }^{7}$.

Adolfo Kaminsky, um dos maiores quadros europeus de falsificação de documentos, atividade que teve sua origem durante a guerra, quando ficou conhecido por salvar milhares de crianças judias, lembra-se das motivações para a sua adesão à

\footnotetext{
${ }^{5}$ Após o golpe de Estado contra Ben Bella, o centro gravitacional da organização passou a ser Paris, e o financiamento passou a ser feito por cotização entre os próprios integrantes de Solidariedade e outras organizações de ajuda ou simpatizantes de esquerda (Entrevista de Maria Amaral, Champigny, França, 08 de maio de 2013). A substituição de Ben Bella por um coronel pouco entusiasta dos movimentos terceiro-mundistas provocou uma vaga de detenções e perseguições no país (PERRAULT, 1984, p. 142).

${ }^{6}$ A Rede continuou ativa até o ano de 1981, quando seus remanescentes foram presos (ROGALSKI, Michel, 1998, p. 189).

${ }^{7}$ Henri Curiel foi desde cedo acusado de ser um agente da KGB (PERRAULT, 1984, p. 193-194). Depoimento de seu filho e jornalista francês, Alain Gresh, afirma que a perfeita reprodução de documentos realizada pelo setor de falsificação da Rede, despertou muitas desconfianças sobre o grupo, ao ponto de Solidariedade ter sido associada aos serviços secretos russos (ROGALSKI, 1998, p. 164).
} 
Rede, "o termo não existia ainda na época, mas eu era profundamente anticolonialista" (KAMINSKY, 2009, p. 105). Ele declara que via o projeto de falsificação de documentos como uma forma de fazer pressão sem entrar na engrenagem da violência, pois, como afirmou em seu livro,

Por toda parte no mundo os povos lutavam pela liberdade. Depois dos dominicanos e dos haitianos, foi a vez de o Brasil ficar sob o jugo de uma ditadura militar em 1964. Em seguida à Conferência Tricontinental de Havana em 1966, em que foi criada a Organização Latino Americana de Solidariedade (OLAS) [...] que congregava os movimentos revolucionários da Argentina, Venezuela, El Salvador, Nicarágua, Colômbia, Peru, Uruguai, Chile unidos pela Revolução na América Latina [...]. Todos esses países vieram se juntar à minha lista [...] (KAMINSKY, 2009, p. 199).

Solidariedade não se limitou apenas a providenciar alojamento, trabalho, documentos ou dinheiro aos exilados políticos, ela ajudou também a remobilizá-los prolongando as técnicas das organizações ou lhes ensinando outras. No início, como constata uma de suas integrantes, as tarefas do grupo eram bastante simples, limitandose a ajudar a retirar pessoas ameaçadas de seus países de origem ou a transportar objetos, passando posteriormente a formar grupos de trabalho setorizados e especializados em explosão de pontes, em falsificação de documentos, em maquiagem, em comunicação, em tradução e em medicina ${ }^{8}$.

Uma das primeiras tarefas da Rede Solidariedade foi auxiliar os militares desertores da Guerra do Vietnã. Depois, prestou sua ajuda aos Panteras Negras tendo-se colocado à disposição da Tunísia, Venezuela e de grande parte dos movimentos de guerrilha da América Latina: Haiti, República Dominicana, Nicarágua, El Salvador, Brasil, Chile, Bolívia e Argentina. Os nacionalistas de Moçambique, no seio da FRELIMO, de Angola e de Guiné-Bissau, também puderam desfrutar dessa ajuda9?.

Reforçada por reconhecidas organizações caridosas que lhes serviam também de cobertura, quando contava com a simpatia de pastores protestantes, padres católicos,

\footnotetext{
${ }^{8}$ AMARAL, Maria. Entrevista. [08 maio 2013]. Entrevistador: Maria Cláudia Badan Ribeiro, Champigny, França, 2012.

${ }^{9}$ A Rede Curiel teve penetração também no Oriente Médio, ajudando palestinos da Organização para a Libertação da Palestina (OLP). Na África do Sul a Rede amparou uma organização branca que ajudava secretamente os Panteras Negras (PERRAULT, 1984, p.109).
} 
sindicalistas ou membros de outras associações (como Socorro Vermelho e CGT), Solidariedade dispunha de uma verdadeira retaguarda humana. Alguns conventos dominicanos também emprestaram seus estabelecimentos para abrigar quadros perseguidos, para a realização de reuniões ou para a preparação de quadros.

Todo ano, segundo nos informa Perrault, organizações humanitárias vertiam para Solidariedade somas variáveis, mas não desprezíveis de dinheiro, fruto da demonstração de uma notável generosidade. Toneladas de medicamentos, por exemplo, foram enviadas às crianças no Vietnã, através da colaboração de organismos como $\operatorname{CIMADE}^{10}$, Liga dos Direitos do Homem e Movimento da Paz (PERRAULT, 1984, p. 148 e p. 231). França Terra de Asilo, por exemplo, surgiu da experiência adquirida por dois exintegrantes da Rede Solidariedade de Curiel, no acolhimento a refugiados ${ }^{11}$.

Se houve esta espécie de "globalização da revolução" por parte das forças de esquerda naqueles anos, as forças de direita tendo à frente os Estados Unidos, organizadas e disponibilizando de maiores recursos financeiros, foram as responsáveis pela criação das escolas de treinamento militar para a eliminação de toda e qualquer oposição política no continente, recorrendo à ideia de fronteiras ideológicas. Se o chamado "Grande Irmão" teve um papel fundamental na repressão na América Latina, outros países como Portugal e França emprestaram seus especialistas para reprimir a luta de resistência ${ }^{12}$. Se houve cooperação francesa na luta contra a guerrilha no Brasil, as forças revolucionárias brasileiras também souberam utilizar as estruturas da esquerda

\footnotetext{
${ }^{10}$ Comité inter mouvements auprès des évacués. A CIMADE é uma associação fundada por protestantes em 1901 e que historicamente presta solidariedade aos estrangeiros. A CIMADE tomou parte em combates emblemáticos pela defesa dos Direitos humanos nos campos de internamento da Segunda Guerra Mundial, ao lado dos argelinos no momento da Guerra de Independência, com os refugiados contra as ditaduras militares da América Latina e da África e junto a centenas de milhares de estrangeiros na França e de refugiados da Europa do Leste (CIMADE, 2009).

${ }^{11}$ DE WANGEN, Sylviane Abou. [02 julho 2013]. Entrevistador: Maria Cláudia Badan Ribeiro, Paris, 2013.

${ }^{12} \mathrm{O}$ coronel salazarista Hermes de Araújo Oliveira, por exemplo, foi convidado a dar aulas sobre Guerra Revolucionária no Brasil, com passagens por Fortaleza, Rio de Janeiro e São Paulo. Paul Aussaresses, general francês, foi o responsável pela instrução das Forças Armadas brasileiras na Selva Amazônica transmitindo os ensinamentos adquiridos na repressão aos nacionalistas argelinos. Muitos testes nucleares conduzidos pela França em seus territórios d'outre-mer serviram como pretexto para treinamentos e emprego de técnicas repressivas, transplantadas depois, por exemplo, no Panamá, sede da escola das Américas instalada por Washington para o treinamento da luta antirrevolucionária (AUSSARESSES, 2008, p.141-162). Cf. ROBIN, Marie-Monique. Escadrons de la mort, l'école française. Paris: Éditions la Découverte, 2004.
} 
clandestina francesa para impulsionar sua luta. Uma das figuras bastante conhecidas no Brasil e que integrou a Rede Solidariedade na Europa foi o militante do PCBR Apolônio de Carvalho $^{13}$. Como afirmou a militante Maria do Amaral,

[...] o golpe de Estado no Chile nos mobilizou. Solidariedade criou um grupo especial, denominado Grupo Jacques para se encarregar de retirar militantes perseguidos e apoiar a resistência interna. Este grupo foi liderado por Apolônio de Carvalho que posteriormente se desentendeu com Curiel [...] (PERRAULT, 1984, p. 286).

O braço da Rede Solidariedade na América Latina era assegurado pela presença no continente de Georges Matté ${ }^{14}$, militante próximo da revista Les Temps Modernes e cofundador junto ao filósofo Francis Jeanson da Rede Jeanson, que antecedeu a Rede de Henri Curiel em apoio à luta de libertação argelina.

Georges Mattéi manteve relações com Cuba, para onde se dirigiu em 1961 com a ideia de transformar Havana na capital de uma internacional latino- americana (GALISSOT, 2009, p. 118-119). Encontrou-se na ilha com Che Guevara, Fidel Castro, Carlos Franqui e Lisandro Otero (EINAUDI, 2004, p. 105) ${ }^{15}$. Também se deslocou por vários países como a Venezuela (tinha relações de proximidade com Douglas Bravo, a quem fornecia documentos), Argentina e Chile (GALISSOT, 2009, p. 120). Encontrou-se no Brasil com

\footnotetext{
${ }^{13}$ Apolônio pertenceu às Brigadas Internacionais e lutou na Guerra Civil Espanhola. Na Resistência Francesa, combateu junto ao Francs-Tireurs et Partisans (FTP). No Brasil foi oposição à ditadura de Getúlio Vargas (1937-1945) e ao Regime militar (1964-1985), tendo pertencido ao Partido Comunista Brasileiro Revolucionário (PCBR). Preso e enviado ao exílio em 1970 em troca da libertação do embaixador alemão Ehrenfried von Holleben, voltou ao Brasil com a Anistia, ajudando a fundar o Partido dos Trabalhadores (PT).

${ }^{14}$ Mattéi participou da Guerra da Argélia, sobre a qual escreveu um livro, La Guerre de Gusses, relatando os horrores que o Exército francês cometia em nome da República. Tornou-se posteriormente integrante da FLN e realizava importantes missões, como se encarregar das saídas pela fronteira de muitos mensageiros. Para maiores informações Cf. MATTEl, Georges. La Guerre des Gusses. Paris: Balland, 1982. Mattéi se juntou à equipe do editor François Maspero para fundar a revista Partisans, da qual foi redator de seu editorial. Posteriormente, deixou o grupo para se integrar aos trabalhos da edição Cujas, que patrocinou um caderno especial dedicado ao Brasil em sua coleção Homens e Ideias do Terceiro Mundo.

${ }^{15}$ Lisandro Otero foi um escritor, jornalista e diplomata cubano. Como jornalista, cobriu a Guerra da Argélia e foi figura presente em momentos históricos, como na Revolução Cultural Chinesa e na queda do muro de Berlim. Ativo militante na revolução cubana, que, como disse, "me ocupou cada minuto", exerceu também o cargo de assessor cultural na embaixada cubana no Chile de Salvador Allende. Cf. OTERO, Lisandro. Llover sobre mojado. Memorias de un intelectual cubano (1957-1997). México, Planeta, 1999. Carlos Franqui foi poeta, jornalista e militante político, participante da revolução cubana, onde dirigia o jornal clandestino da guerrilha Revolución e a estação Radio Rebelde. A partir de 1968 tornou-se um dissidente e ferrenho crítico do regime na ilha.
} 
[...] guardei uma imagem de um homem tranquilo e bonito, totalmente estranho ao delírio exaltante de não sei qual mística do sacrifício e do sangue. Ele se engajou na luta porque ele amava a vida e porque ele considerava que o dever de todo revolucionário é o de fazer a revolução. (EINAUDI, 2004, p. 139-140. Tradução do autor)

Passando por Recife, Mattéi não só visitou Dom Helder Câmara, mas tinha como tarefa contatar um estudante brasileiro para a realização de alguns estágios práticos na Europa (EINAUDI, 2004, p. 140). Outros brasileiros o conheceram em meados de 1965. O francês manteve contatos com diversas tendências políticas, encontrando-se clandestinamente com lideranças da UNE de São Paulo e do Rio de Janeiro, com militantes da VPR, e mesmo no Chile, se reuniu com brasileiros exilados (EINAUDI, 2004: 140-141). Seu auxílio à luta revolucionária brasileira não se limitou apenas a conhecer a realidade brasileira, mas se inseriu na própria logística do exílio, naquilo que os revolucionários chamavam de "turismo político", quando quadros da Rede viajavam aos países do Terceiro Mundo para compartilhar seus conhecimentos.

\section{As fileiras cristãs e um ideal partilhado}

Nada mais natural que a ajuda tenha passado pelos princípios fundamentais do cristianismo, da caridade e da ajuda ao próximo. Palavras como acolhimento, ajuda e assistência já eram velhas conhecidas de uma Europa que experimentara a Guerra.

Nas redes religiosas ligadas a Henri Curiel, distinguiam-se dois tipos se solidariedade, uma de conteúdo essencialmente humanitário e outra de conteúdo político, mesmo que a primeira pudesse estimular a segunda ou se confundir com ela. Afinal, salvando vidas também se preservava militantes decididos a continuar em combate.

\footnotetext{
${ }^{16}$ CUADRADO, Floréal. Entrevista [24 março 2014]. Entrevistador: Maria Cláudia Badan Ribeiro, Maricá, RJ, 2014.
} 
A aceleração que vai produzir a união da militância política com a fé cristã, e neste caso também com a Rede Solidariedade, acontece em consonância com a mutação que ocorria nas fileiras religiosas, em particular a partir de 1968 após a Conferência de Medellín. O Concílio Vaticano II (1962-1965) vai lançar a ideia da transformação da América Latina e de uma igreja voltada ao pobre e adaptada à sociedade moderna. Se o Concílio foi acelerador das tendências engajadas, a Teologia da Libertação marcou uma Igreja que foi da passagem de uma prática caritativa de ajuda ao Terceiro Mundo a uma prática mais política. Fazendo-se esta análise vai se acelerar a tomada de consciência junto aos militantes, laicos, clérigos ou religiosos, engajados no movimento geral de libertação (CHANU, 1978).

Esta evolução de ideias tanto precedeu como acompanhou a ajuda concreta e a solidariedade efetiva com os revolucionários do Terceiro Mundo. Parte da Igreja preparou o terreno à ação prática, vindo se juntar ao combate que teve seu centro nos países subdesenvolvidos. Nesta hierarquia de clérigos engajados podemos citar Guy Riobé, Marius Maziers, Alfred Ancel, Paul Blanquart, entre outros. Entre os católicos de maior destaque na Rede Solidariedade encontravam-se o abade Alexandre Glasberg, o Padre Maurice Barth e o padre René Rognon, membro do Movimento da Paz ${ }^{17}$.

Com sede em Genebra, o Conselho Ecumênico de Igrejas foi ativo na denúncia do Apartheid africano e, mesmo que não tenha distribuído dinheiro para Solidariedade, nunca deixou de estar informado de seus passos e de dar sua aprovação cada vez que um membro de sua direção ia diretamente a Genebra (PERRAULT, 1984, p. 149).

A relação estabelecida entre os oponentes políticos de um lado e a Igreja, de outro, foi alimentada pela adversidade e pela indignação moral que ambas as forças encontraram sob as ditaduras civis militares na América Latina. O sopro de esperança permitido pelo Concílio deu origem às missões das chamadas Equipes do Terceiro Mundo, formada por padres que se deslocavam para outras dioceses para viverem em contato com as populações carentes do Brasil, Argentina, Nicarágua e Guatemala. Eram em sua maioria enviados pela Mission Ouvrière ou pela Mission de France, que reconheciam no trabalho local sua missão apostólica.

\footnotetext{
${ }^{17}$ Por questões de espaço não poderemos falar de cada um e de suas ricas experiências. Cf. VALET, Paul. Prêtre-Ouvrier: Itinéraire d'un ancien jociste. Paris: Karthala, 2008.
} 
Muitos párocos e missionários estrangeiros, que inclusive receberam ordem de expulsão do Brasil pela ditadura, deram sua contribuição pessoal, desenvolvendo trabalhos de catequese nos grotões do Brasil e nas regiões de conflitos agrários naqueles anos. Também dentro de suas atividades, esses eclesiásticos foram transmissores de informações e denúncias ao exterior, a despeito das constantes ameaças de morte, prisão ou expulsão ${ }^{18}$. Em relação à América Latina, os eclesiásticos vindos da Europa desempenharam um papel determinante. Calcula-se que mais de $50 \%$ de padres e religiosos da América Latina tenham sido originários do continente (GAUCHER, 1981, p. 279).

Um destes foi o arcebispo Guy Riobé, que chegou ao Brasil ainda nos anos cinquenta. Ele conheceu Dom Hélder e era um árduo defensor de uma reforma da igreja e da sociedade. Muitos padres e religiosos também chegaram à América Latina pelas suas mãos ${ }^{19}$.

O padre Paul Gauthier, que ensinava Teologia em Dijon, teve uma grande influência no Concílio, no qual criou com outros padres o Movimento da Igreja dos Pobres. Era o início do que mais tarde viria a se chamar Teologia da Libertação ${ }^{20}$. O padre viajava pelo mundo e criava comunidades, sobretudo na América do Sul, tendo estado no Brasil em muitas ocasiões (PERRAULT, 1984, p. 302-303). Gauthier fundou em 1964, junto de Ettore Massina, jornalista da TV pública italiana, a Rede Radié Resch, uma organização humanitária situada em Roma que prestava ajuda aos países do Terceiro Mundo. Radié Resch ajudou a muitos exilados brasileiros ${ }^{21}$.

\footnotetext{
${ }^{18} \mathrm{O}$ Projeto Brasil Nunca Mais indica um número de nove religiosos estrangeiros que foram expulsos do Brasil naquela época. Podemos citar alguns que tiveram problemas com a Justiça Militar (1968-1980), como os padres: François Jentel, Honoré Talpe, Joseph Comblin, Padre Soligo, Padre Wauthier, Alípio de Freitas, Francisco Carlos Velez Gonzales e Vito Miracapillo. Este último expulso em 1980 por se recusar a rezar uma missa em homenagem à Independência do Brasil. Cf. MIRACAPILLO, Vito. II Caso Miracapillo: Paradigma della tensione tra Stato e Chiesa in Brasile. Bologna: Editrice Missionaria Italiana, Quaderni ASAL, Nuova Serie 21, 1981.

${ }^{19}$ De volta à França, e já bispo de Orleans, Riobé vai ser um ativo militante contra o Apartheid africano, contra as torturas na América Latina e contra a venda de armas ao Brasil, Chile e Argentina. Padres franciscanos do grupo Frères du Monde também deixaram a França em 1969 com destino ao Peru, como Olivier Maillard e Berrugain, e à Bolívia, como Pierre Rivals. (GAUCHER, 1981, p. 280).

${ }^{20}$ CATÃO, Frei Francisco Augusto Carmil. Entrevista. [12 abril 2012]. Entrevistador: Maria Cláudia Badan Ribeiro, São Paulo, 2012.

${ }^{21}$ DITTA, Leonardo. Entrevista. [18 maio 2012]. Entrevistador: Maria Cláudia Badan Ribeiro, São Paulo, 2012.
} 
Destacada atuação teve o padre de Bordeaux Antoine Guérin, que viveu no Brasil por trinta anos, convivendo diariamente com Dom Hélder Câmara. Em uma Assembleia Geral, ele falou sobre sua experiência brasileira,

No início do ano de 1970, com Bruno, nós desembarcamos no Brasil [...]. Os quatro primeiros anos foram certamente os mais densos, os mais ricos e os mais felizes de minha vida. Na realidade, Dom Helder Câmara, que tinha pedido ao Prado para enviar dois padres franceses para trabalhos sociais, aceitou que durante muitos anos nós vivêssemos num bairro pobre e trabalhássemos com nossas próprias mãos para poder conhecer esse povo e comunicar mais profundamente à sua vida, suas alegrias, seus sofrimentos, sua cultura, sua religiosidade e suas esperanças. Eliana, uma brasileira havia me dito: "Não se pode falar de Jesus Cristo a pessoas cuja única preocupação é comer!” Era um apelo ao compartilhamento, a viver junto, a sentir na pele e no coração aquilo que estas massas de excluídos viviam e experimentavam[...]. Bruno encontrou um trabalho de ajudante de pedreiro, para reconstruir as calçadas da cidade e eu fui contratado numa fábrica de pilhas elétricas com 1200 operários. Os quatro anos aparentemente perdidos do ponto de vista da ação nos fizeram ganhar muito tempo. Anos de osmose e de novo nascimento [...] vivendo a incerteza do cotidiano das famílias: ir buscar água no pé do morro na fonte pública, tomar ônibus lotados, andar, levar o lixo para queimar, fazer fila durante horas para uma visita médica, jogar dominó com um grupo de homens, participar das festas e dos lutos, ver televisão na casa do vizinho... A presença de um padre no trabalho despertou rapidamente a atenção de toda a fábrica, pois estes operários me viram celebrar uma missa na capela do bairro. Quantas conversas antes, durante e depois do trabalho [...] Tudo isso durante a ditadura militar! Com Bruno, nós não tínhamos ilusões: a pobreza que nós tínhamos escolhido não seria jamais aquela de nossos vizinhos e companheiros de trabalho [...]. Sim, nós seríamos sempre ricos e estrangeiros! O que é certo é que todos estes excluídos com os quais vivemos muito nos enriqueceram e nos evangelizaram $[\ldots] .^{22}$ (Tradução do autor)

No caso brasileiro, o Conselho Ecumênico de Igreja terá grande protagonismo junto aos Conventos e Igrejas Presbiterianas pelo país, que puderam não só retirar pessoas do Brasil, como proporcionar sua chegada em segurança ao exterior. Organismos religiosos colaboraram também com obtenção de fundos de greve para Osasco no final dos anos $1970^{23}$. É propriamente no primeiro decênio da ditadura, como defende Marin,

\footnotetext{
${ }^{22}$ GUÉRIN, Antoine. Dom Helder Câmara (1909-1999), le don de l'amour - L'actualité des profetes. Lettre du Pôle Amérique latine, $n^{\circ} 76$ - mars 200.

${ }^{23}$ ESTEVÃO, Ana Maria Ramos. Entrevista [25 fev. 2010]. Entrevistador: Maria Cláudia Badan Ribeiro, São Paulo, 2010.
} 
“que a igreja brasileira realizará sua formidável transformação, definindo sua autonomia e identidade" (MARIN, 1995, p. 201). Um dos efeitos desta transformação, segundo o autor, é o próprio apoio fornecido em abril-maio de 1980 pelo arcebispo de São Paulo aos metalúrgicos em greve, colocando à disposição suas igrejas para a realização de reuniões, organizando a solidariedade e coleta de alimentos com a aprovação da presidência da Conferência Episcopal.

Um dos fundadores do Mouvement Rencontre de Frères chegou a afirmar que entre o Al-5 e 1973 “o único meio de ação no meio popular era a igreja” e que muitos dos agentes das pastorais eram ligados a grupos clandestinos (PC do B, AP, MR-8). Para estes militantes, a Igreja oferecia, segundo ele, "uma cobertura e um sonho: o de chegar às massas (MARIN, 1995, p. 210)". Segundo o padre Antoine Guérin,

Dom Hélder Câmara fez um pacto com Roger Garaudy, um dos dirigentes do Partido Comunista Francês: "Eu farei tudo para que a Igreja aceite o socialismo e para que vocês comunistas eliminem a relação entre religião e alienação". Em 1973 no documento Eu escutei os clamores de meu povo, publicado em plena ditadura, Dom Hélder com vários Bispos e superiores das Congregações religiosas começam a realizar este pacto: "A classe dominante não tem outra saída para se libertar se não for pelo longo e difícil caminho, já em curso, em favor da propriedade social dos meios de produção". A partir deste documento explosivo, eu fiz uma montagem audiovisual mostrando o contraste entre ricos e pobres e apelos para a construção de uma nova sociedade. ${ }^{24}$ (Tradução do autor)

Com efeito, através de um trabalho integrado junto aos ribeirinhos, algumas freiras e padres não só abrigaram militantes perseguidos, como utilizaram suas competências intelectuais para a conscientização de seus povoados, para a montagem de cooperativas, para o incremento das aulas às crianças. Irmãzinhas de Foucauld, dominicanos, salesianos e seguidores da Teologia da Libertação multiplicavam seus trabalhos junto às comunidades carentes.

Perguntado a respeito da relação entre a Igreja e a militância armada, Hamilton Pereira (Pedro Tierra), uma das pessoas que mais proximidade teve com a experiência Pastoral de S. Félix do Araguaia, afirmou:

24 Fonte http://www.eglise.catholique.fr/actualites/dossiers/dossiers-de-2009/dom-helder-camara-le-donde-lamour-temoignage-du-p-antoine-guerin/> Acesso: 12 dez 2014. 
A posição da equipe da Prelazia de S. Félix com relação às organizações de esquerda, armadas ou não, era de abertura, ou seja, jamais se identificar especificamente com uma ou outra, mas estabelecer laços de solidariedade com todos os que se comprometiam com as lutas dos índios e posseiros. É preciso destacar a presença efetiva de militantes ligados ao $\mathrm{PCdoB}$, talvez a mais expressiva entre todas, pela proximidade geográfica com Xambioá/São Geraldo e pela duração de sua presença na região. Encontrei militantes do $\mathrm{PCdoB}$ anos depois de sair da prisão (1977) atuando na Prelazia, distribuindo e discutindo o Jornal Movimento, contribuindo com matérias, etc ${ }^{25}$.

O Seminário de Padres de Campinas (SP), pertencente à ordem dos claretianos, se encarregava de esconder muitos militantes procurados pela polícia ${ }^{26}$. O bispo Dom Pedro Casaldáliga junto ao Padre Antônio Canuto estiveram na cidade em março de 1969, levando alguns militantes clandestinos da ALN para atuarem no Araguaia em trabalhos de interesse da Igreja, sem, contudo, conhecer a relação destas pessoas com a Ação Libertadora Nacional (ALN). A organização, contudo, sabia que enviava militantes para dar início a um trabalho político na região, uma recomendação de Joaquim Câmara Ferreira, um de seus dirigentes.

Conceição do Araguaia, por exemplo, recebeu a visita de Ivo Lesbaupin no primeiro semestre de 1969. Ali a Ordem Dominicana mantinha um Convento desde o começo do século XX, como base da sua missão entre os índios ${ }^{27}$. Outros militantes também se deslocaram para São Félix do Araguaia para realizar trabalho político como Francisco Negrini Romero. Ele viveu alguns anos na região, levado por Dom Pedro Casaldáliga, e participou do conflito com a CODEARA em 1972, que envolveu o Padre Francisco Jentel. A Companhia de Desenvolvimento do Araguaia (CODEARA) foi uma grande empresa agropecuária que se instalou na região, invadindo terras e impedindo o desenvolvimento da Cooperativa Agrícola Mista do Araguaia, que reunia trabalhadores e posseiros na área. A companhia empreendeu uma verdadeira guerra contra os moradores, com ameaças, invasões de terra, de domicílios e prisões, como relembra Romero:

\footnotetext{
${ }^{25}$ PEREIRA, Hamilton. [Mensagem pessoal]. Mensagem recebida por <mariaclaudia_badanribeiro@yahoo.com.br> em 24 de setembro de 2008.

${ }^{26}$ BURNIER, Diva. Entrevista. [29 julho 2010]. Entrevistador: Maria Cláudia Badan Ribeiro, São Paulo, 2010.

27 PEREIRA, Hamilton. [Mensagem pessoal]. Mensagem recebida por <mariaclaudia_badanribeiro@yahoo.com.br>em 24 de setembro de 2008.
} 
[...] Durou alguns meses assim [o conflito], eles vieram, alguns soldados com jagunços derrubaram a escola que a gente estava fazendo na cidade de Santa Terezinha, um ambulatório, bom, o pessoal ficou revoltado. Nós começamos a construir, eles vieram novamente e com mais gente, derrubaram, só que nessa derrubada, eles tomavam cerveja assim, batiam nos destroços e tirando sarro e o povo vendo. Na terceira vez quando eles vieram o pessoal já tinha organizado uma tocaia. $\mathrm{Na}$ prefeitura de Luciara eu descobri uns papéis do exército que eles mandavam para todas as prefeituras da região, fazendo um levantamento para combater a guerrilha. "Nós precisamos fazer um levantamento de tudo que é possível que os guerrilheiros possam usar, tipo rede, começava com a infraestrutura [...]". Nossa, eu peguei aquilo e mandei para São Paulo. "Olha o que está acontecendo aqui, os caras estão fazendo um levantamento antecipado do que a gente pode fazer". O padre Jentel ia muito à Polícia Federal, batia, batia, ele era tão perseverante que ele conseguiu pegar o mapa aerofotogramétrico da região feito pela Polícia Federal ${ }^{28}$.

O enfrentamento durou seis meses com cerca de 80 pessoas internadas na

floresta. Posseiros puderam contar com a ajuda dos índios tapirapés, que construíram banheiros químicos, ajudaram na montagem de armadilhas na mata, e esconderam os militantes na aldeia. As mulheres de soldados e prostitutas também se aliaram à luta, repassando informações estratégicas e fornecendo alimentos.

[...] elas começaram a fazer a cabeça dos soldados, tanto é que os caras trocaram uma tropa, porque eles não queriam entrar na mata. Porque elas chegavam e falavam, "vocês são camponeses, posseiros, vocês vão atacar os nossos maridos, os nossos irmãos, vocês não pensaram nisso?" Isso que eu achei fantástico nas mulheres, a estratégia, mas não foi a gente que fez isso, você entendeu? Foram elas próprias ou o pessoal da igreja que ajudou a pensar. Uma igreja comprometida com o processo, o quanto que ela colabora no processo político e organizativo da população. [...] Elas estavam apoiando, dando leite, dando farinha, dando comida, mandioca. Uma moça que era argelina, que era quem tinha contato nos prostíbulos e que ajudava as prostitutas a se curar da malária, era uma moça fantástica assim, porque era dali que nós conseguimos tirar as informações das prostitutas sobre a ação da polícia e da CODEARA (grifo do autor) ${ }^{29}$.

28 ROMERO, Francisco Negrini. Entrevista [02 maio 2012]. Entrevistador: Maria Cláudia Badan Ribeiro, Piracicaba, SP, 2012.

${ }^{29}$ Idem. 
Francisco Jentel era vigário de Santa Terezinha, uma paróquia da Prelazia de S. Félix. Seu comprometimento com os ribeirinhos o tornou alvo principal da repressão, quando no conflito contra a empresa CODEARA se estampava no jornal local: "Padre sai da Igreja com duas metralhadoras na mão incentivando a guerrilha" ${ }^{30}$. Como afirmou Hamilton Pereira:

Jentel era um homem de formação conservadora, despolitizado no sentido teórico da palavra, mas profundamente identificado com sua comunidade e o quotidiano de injustiças que sofria. E era um lutador, extremamente prático, corajoso e abnegado. O seu compromisso com os posseiros de Santa Terezinha em luta contra a CODEARA é que foi o pretexto para sua expulsão pelo General Geisel ${ }^{31}$.

No processo movido pela Justiça Militar de Campo Grande, que o condenou a um ano de prisão, um dos juízes auditores, Plínio Barbosa Martins, voto vencido no Conselho Permanente de Justiça (CPJ), defende Jentel dizendo:

Discordo frontalmente da decisão do CPJ [...] porque não vejo na conduta de Pe. F. Jentel a personalidade de um criminoso. Ao contrário, inveja-me sua coragem de abandonar a sua super desenvolvida França e vir há quase 20 anos empenhar-se na Amazônia mato-grossense para dar um pouco de civilização ao índio e brasileiro que naquelas plagas inóspitas viviam [...] Jentel é soldado desse pensar, um exemplo de cristão a ser seguido ${ }^{32}$.

Em Xambioá, muitos padres franceses apoiaram a luta dos posseiros integrados à Pastoral da Terra. Um Convento em Goiás ajudou a retirar militantes perseguidos que se dirigiram posteriormente à Itália ${ }^{33}$.

Os sacerdotes foram também fundamentais no repasse de informações ao exterior. As denúncias realizadas no exterior chegavam à Europa pelas mãos de Dom Pedro Casaldáliga, Tomás Balduíno e pelo padre Renzo Rossi, que, sendo da Pastoral

\footnotetext{
${ }^{30}$ Idem.

${ }^{31}$ PEREIRA, Hamilton. [Mensagem pessoal]. Mensagem recebida por <mariaclaudia_badanribeiro@yahoo.com.br> em 24 de setembro de 2008.

32 Arquivo Edgard Leuenroth, Acervo Brasil Nunca Mais. Processo 634, p. 2.197. Cf. CASALDÁLIGA, Pedro. A condenação de Pe. Jentel, 30 de maio de 1973, p. 1219-1223.

33 ROMERO, Francisco Negrini. Entrevista [02 maio 2012]. Entrevistador: Maria Cláudia Badan Ribeiro, Piracicaba, SP, 2012.
} 
Carcerária retirava documentos, denúncias, recados do interior das prisões ${ }^{34}$. É claro, que naquele contexto, Padre Renzo devia se comportar aos olhos dos generais, como realizando um trabalho essencialmente sacerdotal e caridoso. Não que ele fosse uma pessoa de esquerda, sua motivação, como afirmou Frei Betto (2012), era mais teológica do que ideológica ${ }^{35}$. Denúncias contra a repressão aos índios, assassinatos de camponeses no estado de Goiás, desaparecimento de pessoas, estavam entre algumas das notícias principais desta central religiosa de comunicação. Como afirmou o Padre Antoine Guérin,

Sempre respeitei as pessoas que "trocaram a cruz pela metralhadora". Mas, minha concepção do Evangelho e da vida cristã não me empurravam nesta direção [...]. Naquele documento Eu escutei os clamores de meu povo os bispos e religiosos que assinaram não tomaram uma posição comunista, mas expressaram a fidelidade à doutrina social da Igreja. Dom Hélder não suportava o comunismo. Ele nunca aceitou ir num país comunista... mesmo sendo chamado de bispo vermelho. Ajudar o povo a se organizar, lutando por seus direitos, defender os direitos humanos é a nossa maneira de seguir Jesus e o Evangelho, custe o que custar. Neste caminho agimos com todas as pessoas de boa vontade qualquer que sejam sua ideologia ou seu partido ${ }^{36}$.

Se a cúpula da Igreja no Brasil manteve relação de cumplicidade com a ditadura, tentando conter as influências dos cristãos de esquerda e/ou progressistas, não é menos verdade o que o dirigente Carlos Marighella entrevistado por Conrad Detrez disse, "uma das coisas que mais irrita os generais é que não conseguem lançar a igreja contra os revolucionários. Na nossa luta há religiosos, católicos, espíritas [...] gente do povo que frequenta terreiros 37 ". José Luiz Del Roio, militante da ALN, por exemplo, realizou curso de Marxismo junto ao Padre peruano Gustavo Gutiérrez expoente da Teologia da Libertação na América Latina ${ }^{38}$.

${ }^{34}$ DEL ROIO, José Luiz. Entrevista. [13 abril 2012]. Entrevistador: Maria Cláudia Badan Ribeiro, São Paulo, 2012. Padre Enzo Rossi hospedava perseguidos políticos, emprestava sua casa para reuniões clandestinas e chegou a fazer greve de fome em solidariedade aos presos políticos (JOSÉ, 2002).

${ }^{35}$ BETTO, Frei. Entrevista. [04 maio 2012]. Entrevistador: Maria Cláudia Badan Ribeiro, São Paulo, 2012.

${ }^{36}$ GUÉRIN, Antoine. [Mensagem pessoal]. Mensagem recebida por <mariaclaudia.badanribeiro@gmail.com> em 21 de dezembro de 2014.

${ }^{37}$ Entrevista concedida por Carlos Marighella ao Semanário francês Front. O Brasil será um novo Vietnã, 3 nov. 1969 (mimeo).

${ }^{38}$ DEL ROIO, José Luiz. Entrevista. [13 abril 2012]. Entrevistador: Maria Cláudia Badan Ribeiro, São Paulo, 2012. 
Francisco Negrini Romero conseguiu, através do Conselho Mundial de Igrejas, dez mil dólares para a montagem de um restaurante no Chile que ajudava cinco mil exilados no país ${ }^{39}$. O Convento Saint-Jacques em Paris era o local que prestava ajuda aos brasileiros exilados, e no qual se realizavam seminários e discussões sobre a América Latina. Administrado pelo Padre Maurice Barth, mantinha relações de cooperação com a rede Solidariedade de Curiel ${ }^{40}$. A rede mantinha vínculos estreitos com Jean de La CroixKaelin, padre dominicano, com Robert Davezies, católico ligado à Mission de France, e com o padre argentino Oscar Bracelis. Entre os laicos que a apoiavam estava Jean Marie Domenach, diretor da Revista Esprit (WINECOK, 1975) ${ }^{41}$, e o jornalista Robert Barrat, redator da revista Témoignage chrétien.

Verifica-se assim que algumas estruturas formais de acolhimento aos exilados também foram a ponta de uma cadeia vasta de atividades clandestinas que a precederam ou a originaram. Foi exatamente neste meio religioso, tanto católico como protestante, que Curiel encontrou um trabalho amplificador em relação à Solidariedade, que se funda em conexões com outros organismos, como Movimento da Paz, França Terra de Asilo, Partido Comunista, Socorro Popular e Alto Comissariado das Nações Unidas para Refugiados.

A ideia de um "evangelho libertador" e a opção pelos pobres teve ressonância, por exemplo, na militância do Padre colombiano Camilo Torres. O português Alípio de Freitas também abandonou sua condição de padre para se dedicar exclusivamente à atividade revolucionária (JOSÉ, 2002, p. 83). Abade do Mosteiro de São Bento, na Bahia, Dom Timóteo Anastácio chegou a afirmar: "acho que Marx foi também um profeta numa época em que a própria igreja, o próprio cristianismo estavam vinculados à sociedade de classes. Então Deus mandou ressuscitar um profeta ateu. Sem ele saber, pregando a libertação das massas de toda uma estrutura injusta" (JOSÉ, 2002, p. 78).

\footnotetext{
39 ROMERO, Francisco Negrini. Entrevista [02 maio 2012]. Entrevistador: Maria Cláudia Badan Ribeiro, Piracicaba, SP, 2012.

${ }^{40}$ BARTH, Maurice. Entrevista. [22 julho 2013]. Entrevistador: Maria Cláudia Badan Ribeiro, Paris, 2013.

${ }^{41}$ A revista Esprit é uma revista intelectual que em seu início foi muito influenciada pelo pensamento filosófico de Jacques Maritain.
} 
A ideia do homem novo conquistava mentes e corações dentro da igreja. Aos poucos, segundo afirmou Márcio Moreira Alves, a "Igreja do Silêncio", a "Igreja Padecente" foi "lançando os militantes a um trabalho de evangelização através da mudança de estrutura" (ALVES, 1968, p. 17). Em Minas Gerais, como o ex-deputado relata, enquanto os proprietários de terras contrários à reforma agrária parodiavam o Evangelho dizendo "Armai-vos uns aos outros", o Padre Lage defendia resoluto a necessidade de distribuição da propriedade territorial, sendo espancado e apedrejado pela Polícia de Juiz de Fora (ALVES, 1968, p. 27) ${ }^{42}$.

O Centro do Padre Louis Lebret, na França, estudioso pioneiro da Economia do Desenvolvimento na França durante missões realizadas no Brasil, Líbano e Chile, forneceu trabalho e bolsas aos estudantes brasileiros, estando entre alguns deles militantes da Ação Popular (AP), como José Serra e Jader Soares Resende. Aloysio Nunes Ferreira foi professor do IRFED (Institut Internacional de Recherche et de Formation en vue du Dévelopement Harmonisé), instituto criado em 1958 e inspirado na nova doutrina social lançada pelo Padre Lebret e que será posteriormente reivindicada por outras teorias econômicas na América Latina, num itinerário que vai misturar progressismo cristão, catolicismo social e reunir sindicalistas, engenheiros e padres operários de muitas partes do Terceiro Mundo (PELLETIER, 1966) ${ }^{43}$.

O padre Lebret - falecido no ano de 1966 - foi um dos padres da Encíclica Populorum progressio. Como sublinha parte do texto Fé e Desenvolvimento,

Esta militância foi conduzida pela análise do subdesenvolvimento a um engajamento político para a transformação do sistema internacional. A formação da opinião pública é o seu principal campo de ação. Querendo mobilizar a opinião cristã é necessário traduzir sua prática em prática de fé (PELLETIER, 1966, p. 173).

Outros intelectuais e cristãos progressivos também vão se destacar neste caminho como difusores da solidariedade ao Terceiro Mundo, criando um fórum de debates sobre a questão do desenvolvimento, como Georges Ho Hourdin, com o lançamento da Revista

${ }^{42}$ Cf. PADRE LAGE. O padre do diabo. A Igreja ausente na hora de mudar. São Paulo: EMW, 1988.

${ }^{43}$ Agradeço imensamente à senhora Bernadette Huger, do Centro Lebret-Irfed, que me permitiu acesso à documentação relativa aos professores e ex-alunos brasileiros que passaram pela instituição. 
Croissance des Jeunes Nations, em 1961. A Revista La Lettre, publicada pelo grupo de mesmo nome, cujos integrantes já haviam tido atuação durante o conflito argelino, serão o responsáveis por abrir o debate na França sobre o tema Cristianismo e Revolução, mostrando que a insubmissão era um ato de fé e reunindo nomes como André Mandouze (redator chefe do Caderno Témoignage Chrétien), Jacques Chatagner, do Movimento da Paz, o dominicano Paul Blanquart, membro do comitê de redação de Politique Hebdo, e os pastores Georges Casalis e Jacques Lochard ${ }^{44}$. A Rede Curiel pode contar, por exemplo, com a colaboração direta de Elia Perroy, antiga professora e secretária do La Lettre

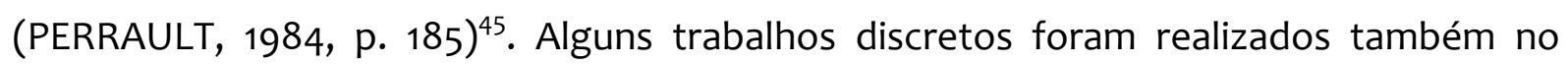
Convento de Arbresle, mantido pelos dominicanos do Convento Sainte-Marie de La Tourette.

Os cristãos vão então paulatinamente se inserindo no processo revolucionário, pois para uma boa parte de religiosos progressistas a maior violência era a sociedade capitalista. Como afirmou Jallès Costa (1968) “a violência revolucionária é temporária. A violência de Estado é permanente" ${ }^{46}$. Outro eclesiástico, Olivier Maillard, do grupo Frères du Monde, chegou a afirmar que

[...] o problema moral - diz ele - não é de saber se a violência é boa ou ruim, permitida ou não. O escândalo moral é que uma criança morra de fome e que um homem seja explorado. É a este nível que deve se situar a moral... O problema não é escolher a violência (...), o problema é o de assumir as situações de violência (GAUCHER, 1981, p. 106. Tradução do autor).

Um mês após maio de 1968, organiza-se, por exemplo, na Sorbonne, um encontro intitulado De Jesus Cristo a Che Guevara, que reúne a irmã Françoise Vandermeersch junto ao padre Jean Mansir, Madeleine Garrigou-Lagrande e o pastor Jacques Beaumont (GAUCHER, 1981, p. 269-270) ${ }^{47}$.

\footnotetext{
${ }^{44}$ Cf. GINLE-LORINET, Sylvaine. Libérer le Prêtre de l' État Clérical. Échanges et Dialogues (1968-1965). Paris: I'Harmattan, 2008.

${ }^{45}$ Cf. LANDRÉ, Sabine. Une femme dans son siècle. Paris: Éditions du Temps Présent, 2011.

${ }^{46}$ Christianisme et révolution, $p, 101$, Supplement $n^{\circ} 119$ de Lettre, 1968.

47 O pastor Jacques Baumont faleceu em 20 de setembro de 2012. Secretário Geral da CIMADE (1956-1968), teve um papel determinante na Guerra da Argélia, instalando equipes nas zonas de conflito e
} 
Claro que, tomando posições mais radicais, estes sacerdotes não abandonaram suas funções específicas, mas funcionaram como parte de uma rede de solidariedade mais ampla. Heinz Dressel, pároco alemão da Igreja Luterana, permitiu acesso aos estudos a brasileiros recém-chegados a Bochum, quando eles ainda não tinham sua situação legalizada no país. Seu lema era: através de becas, salvar vidas. Chegou a negociar diretamente com o Ministro da Educação Jarbas Passarinho a saída de militantes do Brasil, não esperando a hora, como ouviu de um bispo brasileiro, "que a polícia lhes desse caramelos $^{48, "}$.

Frei Giorgio Callegari era um canal de transmissão de informações para o exterior. Preso em 1969, denunciou, por exemplo, a presença de instrutores americanos nos interrogatórios brasileiros.

Frei Betto destaca que o principal contato para a disseminação das denúncias na França era o Padre Charles Antoine, que abastecia de notícias sobre o Brasil o Jornal Le $M_{0}{ }^{49}$. Tendo deixado o Brasil em 1969, Charles Antoine foi o responsável também por publicar o Diffusion de l'information sur l'Amérique latine (DIAL), um boletim de alcance mundial denunciando a ditadura ${ }^{50}$.

Padre Vincent de Couesnongle costumava ir aos presídios visitar os padres presos, e nas palavras de Frei Betto, "ele era o assistente do Superior Geral dos Dominicanos em Roma designado para acompanhar o nosso caso. Em seguida, foi eleito Superior Geral dos Dominicanos no mundo. Ele nos visitava, apoiava, falava em Roma com os Cardeais e com o Papa Paulo VI ${ }^{51 "}$.

Muitos outros exemplos poderiam ser destacados desta ligação frutuosa e ao mesmo acidentada entre fé e marxismo, o que ultrapassa o propósito deste texto. 0

denunciando as torturas. Ele integrou posteriormente a UNICEF e realizou missões no Afeganistão e no Sudeste Asiático.

48 DRESSEL, Heinz. Entrevista. [23 fevereiro 2013]. Entrevistador: Maria Cláudia Badan Ribeiro, Nuremberg, 2013. Pude ter acesso à troca de correspondência entre o Pastor Protestante e Jarbas Passarinho.

${ }^{49}$ BETTO, Frei. Entrevista. [04 maio 2012]. Entrevistador: Maria Cláudia Badan Ribeiro, São Paulo, 2012. Frei Betto, [Mensagem pessoal]. Mensagem recebida por <mariaclaudia_badanribeiro@yahoo.com.br> em 06 de maio de 2012.

50 O acervo da Revista está disponível on-line desde o ano de 2006 e pode ser consultado no site 〈http://www.alterinfos.org/spip. php?rubrique38.. Acesso em outubro 2012. O Arquivo de Charles Antoine encontra-se na Biblioteca de Documentação Internacional Contemporânea (Universidade de Nanterre) e é composto de 357 dossiês cobrindo o período de 1955 a 1995.

${ }^{51}$ BETTO, Frei. Entrevista. [04 maio 2012]. Entrevistador: Maria Cláudia Badan Ribeiro, São Paulo, 2012. 
depoimento de Carlos Eduardo Senna Figueiredo ilustra um pouco as contradições presentes num ideal compartilhado, mas nem sempre convergente,

Fiz Engenharia na Universidade Católica do Rio de Janeiro. Havia grande efervescência política naqueles tempos universitários. Mesmo a Igreja se bifurcava em posições antagônicas. Das alturas de Friburgo saía um jesuíta dos seus cuidados para dar aulas de Marxismo, em horas esconsas, na PUC. Claro está que o propósito desse santo homem era nos levar ao dernier cri do pensamento humanista que, a seu ver, estava plasmado nas ideias de Emmanuel Mounier e de Teilhard de Chardin. Assim, naquela prédica, o Marxismo seria o prólogo e Mounier o grand finale. Mounier e Teilhard de Chardin, a seu ver, eram a cereja do pudim que nos trazia o Padre Henrique de Lima Vaz de Friburgo ${ }^{52}$.

\section{As alianças latino-americanas}

Se a união das esquerdas não aconteceu de forma permanente no Brasil, ela se deu de formas mais esparsas pela América Latina ${ }^{53}$. Se a Operação Condor atuava no Cone Sul, a solidariedade revolucionária colocou seus protagonistas diversas vezes em contato.

Se a rede de Solidariedade de Henri Curiel lançou seus braços na América Latina, possibilitando passagem e refúgio a muitos revolucionários, houve no Brasil e em outros países da América do Sul várias contribuições que permitiram muitas atividades entre militantes, a começar por facilitar o trânsito pela fronteira, dar guarida a outras organizações revolucionárias, providenciar armas, contingente e dinheiro, ou atuar conjuntamente nas denúncias contra a violência das ditaduras militares no continente.

Os esquemas de saída dependiam tanto da boa vontade de pessoas - em especial ligadas ao partido ou simpáticas a ele - quanto do compromisso estabelecido no interior das organizações de luta armada. Havia pelo menos três esquemas organizados de saída do Brasil. Um dominado pelos dominicanos em Porto Alegre, outro utilizado pelo Uruguai

\footnotetext{
52 SENNA, Carlos. Entrevista [28 junho 2012]. Entrevistador: Maria Cláudia Badan Ribeiro, Rio de Janeiro, 2012.

53 CORREIA, Itobi Alves. Entrevista. [16 maio 2012]. Entrevistador: Maria Cláudia Badan Ribeiro, São Paulo, 2012.
} 

(ALN) consistiu em dar apoio logístico aos revolucionários. Encarregavam-se de esconder pessoas, cuidar dos feridos, levantar áreas para futura guerrilha - como foi o caso da região do Araguaia - e retirar pessoas do país. Funcionavam como propagadores da concepção política da organização, angariando simpatias e aumentando seus quadros. Frei Betto, chefe de reportagem da Folha da Tarde, por exemplo, integrou à organização o diretor de seu Jornal, o jornalista Jorge de Miranda Brandão, aliás, a primeira pessoa a ser retirada do país pelo esquema montado pelos dominicanos na fronteira. Embora preso no Uruguai, sua relação com Frei Betto nunca foi descoberta. Jorge Miranda Brandão saiu do país levando uma mensagem de Carlos Marighella para Fidel Castro, costurada em sua gravata ${ }^{55}$.

Pelos dominicanos saíram cerca de dez pessoas do país ${ }^{56}$. Frei Betto também afirma que levou armas e bombas para o Sul a pedido do dirigente, escondendo-as no Convento das Monjas Cônegas de Santo Agostinho. Mas, ressalta: “eu podia estar morto,

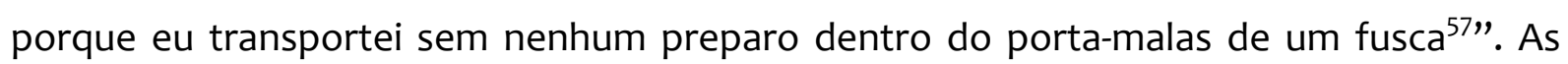
armas se destinavam à montagem de uma base da organização no estado do Paraná.

O esquema de fronteira foi montado através de uma rede, que contou com a solidariedade de outras pessoas ligadas à organização ou de padres interessados em preservar a vida dos perseguidos, desconhecendo suas relações com Carlos Marighella. Os militantes utilizavam então a Paróquia de Piedade como ponto de passagem. Como afirmou Frei Betto: “nunca saí da área da grande Porto Alegre e nunca viajei com ninguém para Santana do Livramento, nem para Rivera" 58 . Os croquis dando as instruções

\footnotetext{
${ }^{54}$ Houve pessoas que deixaram o país pelo estado do Mato Grosso, chegando à Bolívia, por exemplo, e outros que atravessaram sozinhos pelas fronteiras, utilizando esquemas pessoais, como foi o caso de Carlos Eugênio Paz.

55 Preso em Montevidéu, Jorge Miranda conseguiu se desvencilhar do documento atirando-o num vaso sanitário.

${ }^{56}$ Cf. BETTO, Frei. Batismo de Fogo. Rio de Janeiro: Bertrand Brasil, 1987. Frei Betto, [Mensagem pessoal]. Mensagem recebida por <mariaclaudia_badanribeiro@yahoo.com.br> em 06 de maio de 2012.

${ }^{57}$ BETTO, Frei. Entrevista. [04 maio 2012]. Entrevistador: Maria Cláudia Badan Ribeiro, São Paulo, 2012.

${ }^{58} \mathrm{Idem}$.
} 
iam de ônibus a Montevidéu. Pessoas como o Sr. Braz, um funcionário da Aduana, era o contato através do qual se conseguiam documentos para a entrada de brasileiros no país.

Voltando ao Brasil depois de expulso em 1967 pelo governo militar brasileiro, o escritor e militante Conrad Detrez contou com a ajuda de Frei Betto para se encontrar com Marighella clandestinamente. Foi Frei Betto quem permitiu que Detrez realizasse a última entrevista em vida de Carlos Marighella, publicada na revista Front em novembro de 1969.

A Livraria Duas Cidades era também um ponto de apoio da militância, através da qual os freis dominicanos ajudavam militantes perseguidos, conseguiam documentos e davam apoio àqueles que haviam sido torturados ${ }^{59}$.

A região sul do país, através de estancieiros que tinham ligação com o Partido Comunista ou com o governo de João Goulart, também foi utilizada como rota de fuga. Havia gente comprometida em dois jornais de tendências trabalhistas em Santana do Livramento, como A Plateia e Folha Popular. O proprietário da Folha, Ivo Caggiani, por exemplo, tinha contato com um funcionário da polícia civil que providenciava documentos falsos.

Muitas famílias deram colaboração na fronteira. Eram brasileiros que também em fuga fixaram-se em Rivera e serviram como pombo-correio ou realizavam demais tarefas para os militantes. Entre alguns nomes mais conhecidos, que colaboraram em 1964, logo após o golpe, em 1967 e 1968, estão Orlando Burmann, ex-prefeito e deputado estadual de ljuí, que se instalou em Rivera em 1966. Como era temerário embarcar em rodovia e ferrovia, o político usava seu carro para retirar gente. Burmann fez parte da resistência de Brizola e realizou várias viagens ao Brasil para estabelecer contatos em quartéis, sob a capa de vendedor de consórcio de carros (ASSEFF, 2009, p.113).

\footnotetext{
59 Marighella podia contar com outras colaborações, como um funcionário no interior da própria polícia, que fazia documentos falsos. O estúdio fotográfico montado por Frei Betto e por Carlos Eduardo Pennafiel Filho também se encarregava da produção de documentos.
} 
Romeu Figueiredo de Mello trabalhava com processamento de café na fronteira, tinha sido militar da FEB e lutado na Itália. Pela sua casa passaram Jeferson Cardim, Alcyndor Aires e Oscar Fountoura Chaves (ASSEFF, 2009, p.141). Os irmãos Aquiles e Perseverando Santana Alves ajudaram Joaquim Câmara Ferreira, Roberto Morena, Armênio Guedes, Tarso Genro e Edmur Péricles Camargo a deixar o Brasil. Manuel Luiz Coelho ajudava uruguaios a entrarem no Brasil (ASSEFF, 2009, p. 154 e segs.) ${ }^{60}$.

Outras redes também procuraram combater as ditaduras na América Latina, reunindo de brasileiros a chilenos, uruguaios e argentinos. A chamada Rede Vinicius, fundada por um argentino da antiga Coluna Guerrilheira de Che Guevara, por exemplo, se responsabilizava pela retirada de militantes brasileiros do país ${ }^{61}$. Colaborava com esta Rede o professor Joel Rufino, que foi preso sob a seguinte alegação:

O crime narrado na denúncia tem feição gravíssima, pois a prova indiciária, si et in quantum, revela que este réu, que é professor e criador de história, constituiu, com colaboração de outros acusados, uma 'agência' para facilitar a entrada de terroristas no país e propiciar a fuga de criminosos políticos, de notória periculosidade, até para o exterior, dificultando, por isso mesmo, a ação dos órgãos mantenedores da Segurança Nacional e facilitando, mediante tal prestação de serviços, as atividades dos fanáticos que tentam comunizar o Brasil ${ }^{62}$.

Parte dessa rede de apoio também contou com uma Casa de Repouso no município de Santo André (SP), onde os perseguidos pernoitavam como supostos “pacientes”, para deixarem o país logo em seguida. Recados também foram levados para o exterior no interior de comprimidos de optalidon ${ }^{63}$.

Outras rotas de fuga ou de entrada no Brasil, se não partiram do sequestro de aviões ou da captura de personalidades públicas, dependeram de planos arquitetados em

\footnotetext{
${ }^{60}$ Outros nomes aparecem como parceiros de travessia, como Nery Medeiros, Adan Fajardo, Francisco Fagundes e Antônio Apoitia Neto.

${ }^{61}$ MOLES, Alfredo. Entrevista [10 janeiro 2013]. Entrevistador: Maria Cláudia Badan Ribeiro. Barcelona, 2013. Cf. também o livro do jornalista Mário Magalhães, Marighella: o guerrilheiro que incendiou o mundo. São Paulo: Companhia das Letras, 2012, p. 509-510. Alfredo acredita que conseguiu retirar cem pessoas do Brasil.

${ }^{62}$ Arquivo Edgard Leuenroth (AEL-UNICAMP). Acervo Brasil Nunca Mais, Processo $\mathrm{n}^{\circ}$ 203. SANTOS, Joel Rufino. Entrevista. [27 abril 2012]. Entrevistador: Maria Cláudia Badan Ribeiro, Rio de Janeiro, 2012.

${ }^{63}$ SOLITRENICK, Regina Elza. [15 abril 2012]. Entrevistador: Maria Cláudia Badan Ribeiro, São Paulo, 2012.
} 

junto a funcionários do corpo diplomático.

Estes últimos foram muito importantes também, sobretudo porque além da existência de uma lista de proscritos mantida em sigilo pelo Itamaraty ${ }^{64}$ havia um debate constante - particularmente durante os sequestros de aeronaves - entre o Ministério Público e os Promotores Militares acerca do alcance da jurisdição penal brasileira, para atos que, cometidos fora do país, tivessem efeitos no Brasil. Tentava-se com essa manobra jurídica conter a oposição brasileira no exterior, somando-se a ela a presença de agentes do SNI nas embaixadas, agentes diplomáticos calados pelo medo de ver suas carreiras públicas prejudicadas, sem falar na ingerência dos serviços de segurança na vida privada dos brasileiros, abrindo suas correspondências e realizando relatórios sobre os seus passos. Como afirmou Carlos Eduardo Senna Figueiredo, quando estava em Londres,

Ninguém podia contar com o apoio dos serviços diplomáticos brasileiros. Salvo alguns poucos diplomatas que não logravam conciliar o sono, assombrados com o terror que lhes infundiam as possíveis maquinações dos exilados, os demais em geral os mais graduados nas embaixadas brasileiras da época, ignoravam a população exilada, deixando até mesmo de servir os filhos dos brasileiros no ostracismo ${ }^{65}$.

Rompendo este "muro, este silêncio e esta conspiração", Itobi Alves Correia destaca a ajuda prestada pelo cônsul Washington Luís de Souza Neto, neto do expresidente Washington Luís, em conseguir documentos e passaportes para os brasileiros em Paris ${ }^{66}$. Foram estes funcionários "transgressores da lei e da ordem" que salvaram vidas, ajudando, por exemplo, a agilizar um processo de cidadania estrangeira, em especial para militantes com direito à dupla nacionalidade que estavam sendo

\footnotetext{
${ }^{64}$ SENNA, Carlos. Entrevista [28 junho 2012]. Entrevistador: Maria Cláudia Badan Ribeiro, Rio de Janeiro, 2012.

${ }^{65}$ SENNA, Carlos. Entrevista [28 junho 2012]. Entrevistador: Maria Cláudia Badan Ribeiro, Rio de Janeiro, 2012.

${ }^{66}$ CORREIA, Itobi Alves. Entrevista. [16 maio 2012]. Entrevistador: Maria Cláudia Badan Ribeiro, São Paulo, 2012.
} 

fato de estas pessoas viverem na legalidade.

Um caso interessante de solidariedade ocorreu, por exemplo, na Bolívia, quando um embaixador anunciou uma pescaria no Lago Titicaca. Em uma madrugada muitos carros oficiais chegaram com suas bandeirinhas oficiais, aguardando dezenas de pessoas para serem levadas de barco ao Peru. Enquanto metade dos funcionários da embaixada davam cobertura para essas pessoas atravessarem o lago - por pontos menos visados pela polícia - outra metade deles foi comprar peixe, na intenção de manter sob sigilo o trabalho de retirada das pessoas ${ }^{68}$.

Numa entrevista difundida pela Frente Brasileira de Informações (FBI), com sede na Argélia, Carlos Lamarca dizia: "não podemos separar a revolução brasileira do contexto revolucionário da América Latina. Cada país se constitui ao mesmo tempo numa frente e numa retaguarda para os outros" ${ }^{69}$. Um exemplo dessa cooperação foi a implantação de Ernesto Che Guevara em território boliviano, possibilitada por Farid Helou, militante brasileiro que organizou a chegada do argentino à fronteira ${ }^{70}$.

No ano de 1967 estourou na Amazônia um movimento liderado por um venezuelano que estava em Manaus. Subindo o Rio Negro em um navio, pretendia-se levar cerca de vinte militantes de Manaus e Belém para treinamento de guerrilha nas selvas da Venezuela. Presos políticos que conviveram com este guerrilheiro no Presídio na Ilha Grande (RJ) souberam por conversas que o militante realizava um trabalho junto aos índios ianomâmis para permitir uma rota de fuga para os guerrilheiros. Os jornais da

\footnotetext{
${ }^{67}$ Um exemplo deste caso foi o do militante da Vanguarda Popular Revolucionária (VPR) Ladislau Dowbor.

${ }^{68}$ Depoimento de uma fonte que prefere manter seu anonimato.

${ }^{69}$ Centro de Documentação e Memória da UNESP (CEDEM). Front Brésilien d'Information (FBI) n 11, 15 de julho de 1970, p. 5-6.

${ }^{70}$ Farid Helou foi membro do PCB e da ALN e esteve em Cuba em missões como cooperante. Entrevista de Itobi Alves Correia, São Paulo, 16 e 18 de maio de 2012.
} 
época noticiavam que o grupo, composto por estudantes e demais simpatizantes, estava "lançando a semente da rebelião no extremo norte do país"71.

Tupamaros e brasileiros também se uniram em denúncias na América do Sul contra a entrada clandestina de comandantes nazistas no continente e encabeçaram campanhas de boicote às empresas alemãs, que também se beneficiavam do "milagre econômico" brasileiro, como Daimler-Benz, BASF e Volkswagen ${ }^{72}$.

No Brasil, José Luiz Del Roio deu colaboração aos revolucionários argentinos da FAP (Fuerzas Armadas Peronistas), que haviam realizado em Tucumán a Guerrilha do Taco Ralo, refugiando-se no Brasil em $1965{ }^{73}$. Foi também através da embaixada da Coréia do Norte em Cuba que ele junto de mais dois companheiros de organização iniciaram as tratativas para a ALN enviar militantes para treinamento.

O Peru, pelos condicionamentos geográficos, recebia também muitos argentinos e bolivianos em luta contínua contra os seus governos. Enquanto um grupo melhor estruturado no país, os brasileiros puderam dar seu apoio a Montoneros e a alguns bolivianos do Exército Tupac Katari ${ }^{74}$. Uma rota de fuga alternativa também foi tentada pelos brasileiros no Peru, dado que as principais rotas de saída pela Argentina e Uruguai começavam a ficar comprometidas com as ameaças de golpe nos respectivos países ${ }^{75}$. A negociação com o governo peruano era realizada por Darcy Ribeiro e Luís de Almeida. Darcy possuía estatura moral e política para conseguir tal aproximação, pois havia sido

\footnotetext{
${ }^{71}$ Nesse momento no Brasil estava sendo instalada a Zona Franca de Manaus, bem como se iniciavam as primeiras instruções de guerrilha na Selva com a implantação do CICS (Centro de Instrução de Guerra na Selva), comandado pelo Tenente Coronel Jorge Teixeira, também o Encarregado do Inquérito relativo ao grupo. Os fatos se passaram em Manaus, mas o processo foi feito no estado do Pará, na $8^{\text {a }}$ Região Militar. Agradeço ao cineasta Aurélio Michiles pelas informações prestadas com relação ao episódio, sugestões de textos e por ter enviado o roteiro de seu filme. Igual agradecimento devo a Renato Tapajós e a Rômulo Noronha de Albuquerque.

${ }^{72}$ APERJ, cx 598, maço 5, fl. 61. Documentos recentemente conseguidos junto ao governo alemão, no BStU Die Behörde des Bundesbeauftragten-STASI ARCHIV, comprovam esta ligação. O serviço secreto da Alemanha Oriental estava muito bem informado acerca das relações entre a Alemanha Ocidental e o Brasil durante o regime militar.

73 A FAP foi criada em 1968 sob a liderança de Envar Cacho El Kadri, da juventude peronista.

${ }^{74}$ DEL ROIO, José Luiz. Entrevista. [13 abril 2012]. Entrevistador: Maria Cláudia Badan Ribeiro, São Paulo, 2012. O grupo Tupac Katari foi o primeiro grupo a lutar pelos recursos naturais, pela terra e pelo território, lançando as bases do movimento indígena na Bolívia.

${ }^{75}$ Apesar dos esforços, o trabalho não teve resultados, pois o exército peruano começou paulatinamente a reforçar também suas fronteiras amazônicas. DEL ROIO, José Luiz. Entrevista. [13 abril 2012]. Entrevistador: Maria Cláudia Badan Ribeiro, São Paulo, 2012.
} 
assessor de Salvador Allende e responsável por escrever alguns discursos do presidente chileno ${ }^{76}$.

Os contatos de Paulo Cannabrava na Bolívia foram trazidos de Cuba. Cannabrava foi um dos primeiros militantes da ALN a traduzir o livro de Régis Debray Guerra de Guerrilhas para difusão interna na organização. Divulgou amplamente o encontro da Organização Latino-americana de Solidariedade (OLAS) quando trabalhava na sede brasileira da agência Prensa Latina ${ }^{77}$.

Como ele diz, "fui militante boliviano, fui militante peruano. Fazíamos reuniões com os Tupamaros, eu, o Neiva [Moreira] e o Carlos Sá, conspirando e andando na praia

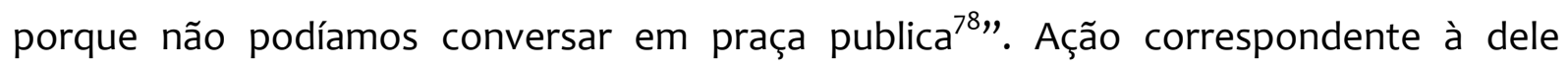
também era encontrada junto aos revolucionários vizinhos, como afirma: "se eu quisesse entrar no Brasil, eu podia também contar com a ajuda dos Montoneros, conseguir documentação, etc."79

Régis Debray a pedido de Che Guevara tinha como tarefa, antes de sua prisão, encontrar-se com Carlos Marighella no Brasil, para fortalecer os laços revolucionários ${ }^{80}$. 0 jornalista Paulo Cannabrava narrou em seu livro um encontro que aconteceu entre Carlos Marighella e o guerrilheiro argentino:

Nos primeiros dias de novembro de 1966, Che Guevara passou por São Paulo, a caminho da Bolívia. Foi recebido por Farid Helou e ficou hospedado no Hotel Samambaia, no centro da cidade, disfarçado de executivo uruguaio. Os cubanos sabiam que havia comunistas que estavam propensos à luta armada. Che Guevara reuniu-se longamente com Carlos Marighella e Câmara Ferreira, principais articuladores do grupo paulista de oposição ao Comitê Central do PCB que propunham a luta armada. Ao final, estabeleceram um acordo no qual os comunistas

${ }^{76}$ CANNABRAVA, Paulo. Entrevista. [17 maio 2012]. Entrevistador: Maria Cláudia Badan Ribeiro, São Paulo, 2012.

77 Paulo Cannabrava foi correspondente da Prensa Latina no Brasil até 1968, quando deixou o país. Trabalhou posteriormente na Radio Havana em Cuba, na Agência France Press na Bolívia, e no Peru foi editor do El Nacional e do Expreso de Lima. Gostaria de destacar que Carlos Marighella nunca foi adepto da teoria do foco. Em seus documentos ele destacava "a guerrilha não é um foco". O dirigente deixou isto bem claro em entrevista ao jornalista Conrad Detrez para a Revista Front em 1969.

${ }^{78}$ CANNABRAVA, Paulo. Entrevista. [17 maio 2012]. Entrevistador: Maria Cláudia Badan Ribeiro, São Paulo, 2012.

79 CANNABRAVA, Paulo. Entrevista. [17 maio 2012]. Entrevistador: Maria Cláudia Badan Ribeiro, São Paulo, 2012.

${ }^{80}$ DEBRAY, Régis. Entrevista. [23 outubro 2012]. Entrevistador: Maria Cláudia Badan Ribeiro, Paris 2012. 
dariam apoio logístico à passagem de revolucionários e armas por território brasileiro e ganhariam o esquema de comunicação entre Che e Cuba (CANNABRAVA, 2003, p. 110).

O Partido Comunista brasileiro tinha relações com o Partido Uruguaio, com o Partido Paraguaio, que inclusive, segundo Cannabrava, chegou ao Brasil para fazer fundos para a revolução paraguaia. Os primeiros bancos expropriados, segundo ele, o foram por paraguaios $^{81}$.

Não podemos desprezar os contatos entre os partidos comunistas mundo afora. Sua máquina era bem organizada com células, contatos e até a prosaica, mas necessária, conta bancária. Saber utilizar esta estrutura era fundamental para a articulação guerrilheira latino-americana. Como afirmou Cannabrava, a frase dita em outros países, "eu sou um comunista brasileiro", abria portas. Como ele declarou, "eu nunca abdiquei que nos éramos do Partido, quem rompeu conosco foi o Comitê Central, nós nunca quisemos romper com ele". As ligações entre o PCB e os outros partidos comunistas o levaram à Coréia do Norte, lugoslávia, Tchecoslováquia, Itália, Argélia e Moscou, aonde em suas palavras, ele chegava para "cobrar fidelidade ${ }^{82 "}$. Segundo diz, se Cuba era elemento de ligação, "eu não precisei de Cuba para articular com os argentinos"83. Do apoio dos Partidos Comunistas europeus e latino-americanos ele conseguia passaportes, passagens, ajuda financeira, rotas de saída e entrada, e divulgação da luta brasileira. Foi ele quem, chegando a Cuba, por exemplo, levou o primeiro documento escrito pelo Pronunciamento do Agrupamento Comunista de São Paulo, que viria a se tornar a ALN posteriormente ${ }^{84}$.

81 CANNABRAVA, Paulo. Entrevista. [17 maio 2012]. Entrevistador: Maria Cláudia Badan Ribeiro, São Paulo, 2012.

82 Paulo Cannabrava também esteve na Bolívia, Peru, Panamá e Nicarágua. Apoiador do Encontro de Lisboa, de refundação do movimento brizolista no PDT, Cannabrava declara que foi Omar Torrijos quem deu passagem para que os militantes que estavam no México e em Nova lorque pudessem ir a Lisboa. Foram também os contatos estabelecidos na Argélia e com representantes dos movimentos revolucionários da África que surgiu a ideia dos Cadernos do Terceiro Mundo.

${ }^{83}$ Os argentinos a que Paulo Cannabrava se refere são os Montoneros, Partido Comunista argentino e o Exército Revolucionário do Povo (ERP).

${ }^{84}$ Cannabrava foi trabalhar na Rádio Havana Clube por recomendação de Joaquim Câmara Ferreira. Em Frankfurt, Alemanha, Cannabrava deixou todos os escritos de Carlos Marighella para serem também publicados. 
Luiz Carlos Prestes, por exemplo, continuava sendo o quadro de referência para o Partido Comunista Italiano ( $\mathrm{PCl})$, e os contatos no mundo socialista continuaram a ser realizados em ajuda aos brasileiros a partir das ramificações de sua estrutura, como a Federação Mundial da Juventude Democrática, a Federação Sindical Mundial em Praga, a União Internacional dos Estudantes na Hungria, a União Mundial de Mulheres em Berlim Oriental $^{85}$. Quando houve a Batalha do Canal do Panamá, Cannabrava relata que

[...] pouca gente sabe é que estava tudo preparado para explodir o Canal. Em cada lugar do mundo que eu fui eu cheguei com o discurso de que tínhamos que ter o apoio internacional por uma luta de libertação. [...] Tudo que estava armado em função do Canal foi para a Nicarágua. 600 homens preparados foram para a Nicarágua ${ }^{86}$.

O treinamento de brasileiros do II Exército em Cuba também contou, por exemplo, com o reconhecimento de Fidel Castro da liderança de Joaquim Câmara Ferreira, após o assassinato o assassinato de Carlos Marighella ${ }^{87}$.

Pelo acima exposto, observa-se que a solidariedade revolucionária foi alimentando e enriquecendo o inventário das lutas na América Latina, forçando acordos internacionais, mudando a paisagem política do século $\mathrm{XX}$, criando uma identidade particular para cada grupo ou país envolvido. Falar sobre estas redes políticas móveis nos ajuda a compreender a gênese social e histórica deste combate que forjou laços revolucionários transnacionais. Na ânsia de continuarem, e contrariando as condições para um recuo da luta por parte dos revolucionários, houve sempre quem os ajudasse.

\footnotetext{
${ }^{85}$ DEL ROIO, José Luiz. Entrevista. [13 abril 2012]. Entrevistador: Maria Cláudia Badan Ribeiro, São Paulo, 2012.

${ }^{86}$ CANNABRAVA, Paulo. Entrevista. [17 maio 2012]. Entrevistador: Maria Cláudia Badan Ribeiro, São Paulo, 2012. Cf. também CANNABRAVA, 2003, p. 254-274.

${ }^{87}$ CORREIA, Itobi Alves. Entrevista. [16 maio 2012]. Entrevistador: Maria Cláudia Badan Ribeiro, São Paulo, 2012.
} 


\section{Referências}

\section{Entrevistas realizadas no Brasil:}

ANÔNIMO. Entrevista. [25 maio 2012] Entrevistador: Maria Cláudia Badan Ribeiro, Rio de Janeiro, 2012. (Entrevista não gravada a pedido do entrevistado)

BETTO, Frei. Entrevista. [04 maio 2012]. Entrevistador: Maria Cláudia Badan Ribeiro, São Paulo, 2012. Entrevista realizada no Convento dos Dominicanos em São Paulo.

BETTO, Frei. [Mensagem pessoal]. Mensagem recebida por <mariaclaudia_badanribeiro@yahoo.com.br>em 06 de maio de 2012.

BURNIER, Diva. Entrevista. [29 julho 2010]. Entrevistador: Maria Cláudia Badan Ribeiro, São Paulo, 2010. Entrevista realizada na FFLCH- USP.

CANNABRAVA, Paulo. Entrevista. [17 maio 2012]. Entrevistador: Maria Cláudia Badan Ribeiro, São Paulo, 2012. Entrevista na residência do entrevistado.

CATÃO, Frei Francisco Augusto Carmil. Entrevista. [12 abril 2012]. Entrevistador: Maria Cláudia Badan Ribeiro, São Paulo, 2012. Entrevista na residência do entrevistado.

CORREIA, Itobi Alves. Entrevista. [16 e 18 maio 2012]. Entrevistador: Maria Cláudia Badan Ribeiro, São Paulo, 2012. Entrevista na residência do entrevistado.

CUADRADO, Floréal. Entrevista [24 março 2014]. Entrevistador: Maria Cláudia Badan Ribeiro, Maricá, Rio de Janeiro, 2014. Entrevista na residência da entrevistadora.

DEL ROIO, José Luiz. Entrevista. [13 abril 2012]. Entrevistador: Maria Cláudia Badan Ribeiro, São Paulo, 2012. Entrevista realizada na sede do CEDEM-SP.

DITTA, Leonardo. Entrevista. [18 maio 2012]. Entrevistador: Maria Cláudia Badan Ribeiro, São Paulo, 2012. Entrevista realizada na Livraria Cultura, Conjunto Nacional.

ESTEVÃO, Ana Maria Ramos. Entrevista [25 fevereiro 2010]. Entrevistador: Maria Cláudia Badan Ribeiro, São Paulo, 2010. Entrevista na residência da entrevistada.

GUÉRIN, Antoine. [Mensagem pessoal]. Mensagem recebida por <mariaclaudia.badanribeiro@gmail.com> em 21 de dezembro de 2014. Questões respondidas de João Pessoa.

NORONHA, Rômulo. [Mensagem pessoal]. Mensagem recebida por <mariaclaudia.badanribeiro@gmail.com> em 11 de março de 2014. Questões respondidas do Rio de Janeiro. 
PEREIRA, Hamilton. [Mensagem pessoal]. Mensagem recebida por $<$ mariaclaudia_badanribeiro@yahoo.com.br> em 24 de setembro de 2008. Questões respondidas de Brasília, DF.

ROMERO, Francisco Negrini. Entrevista [02 maio 2012]. Entrevistador: Maria Cláudia Badan Ribeiro, Piracicaba, SP, 2012. Entrevista na residência do entrevistado.

SANTOS, Joel Rufino. Entrevista. [27 abril 2012]. Entrevistador: Maria Cláudia Badan Ribeiro, Rio de Janeiro, 2012. Entrevista na residência do entrevistado.

SENNA, Carlos. Entrevista [28 junho 2012]. Entrevistador: Maria Cláudia Badan Ribeiro, Rio de Janeiro, 2012. Entrevista na residência do entrevistado.

SOLITRENICK, Regina Elza. [15 abril 2012]. Entrevistador: Maria Cláudia Badan Ribeiro, São Paulo, 2012. Entrevista na residência da entrevistada.

TAPAJÓS, Renato. [Mensagem pessoal]. Mensagem recebida por <mariaclaudia_badanribeiro@yahoo.com.br> em 23 de maio de 2011. Questões respondidas de Barão Geraldo, Campinas, SP.

\section{Entrevistas realizadas no exterior:}

ALMADA, Martin. [Mensagem pessoal]. Mensagem recebida por <mariaclaudia_badanribeiro@yahoo.com.br> em 18 de abril de 2013. Questões respondidas do Paraguai.

DEBRAY, Régis. Entrevista. [23 outubro 2012]. Entrevistador: Maria Cláudia Badan Ribeiro, Paris 2012. Entrevista na residência do entrevistado.

DRESSEL, Heinz. Entrevista. [23 fevereiro 2013]. Entrevistador: Maria Cláudia Badan Ribeiro, Nuremberg, 2013. Entrevista na residência do entrevistado.

FOUCHER, Mariza de Melo. [04 julho 2013]. Entrevistador: Maria Cláudia Badan Ribeiro, Paris, 2013. Entrevista na residência da entrevistada.

JOINET, Louis. Entrevista. [ $1^{\circ}$ de julho 2013]. Entrevistador: Maria Cláudia Badan Ribeiro, Paris, 2013. Entrevista realizada no seu café predileto Café Déjazet, metrô Republique.

LÖWY, Michael. Entrevista. [08 fevereiro 2013]. Entrevistador: Maria Cláudia Badan Ribeiro, Paris, 2013. Entrevista na residência do entrevistado.

LUTZÖW, Britta. Entrevista. [02 junho 2013]. Entrevistador: Maria Cláudia Badan Ribeiro, Berlim, Alemanha, 2013. Entrevista na residência da entrevistada.

MASPERO, François. Entrevista. [30 janeiro 2013]. Entrevistador: Maria Cláudia Badan Ribeiro, Paris, 2013. Entrevista na residência do entrevistado. 
MEIGNAN, Maria Lali Carneiro. [23 junho 2013]. Entrevistador: Maria Cláudia Badan Ribeiro, Paris, 2013. Entrevista na residência da entrevistada.

MOLES, Alfredo. Entrevista [10 janeiro 2013]. Entrevistador: Maria Cláudia Badan Ribeiro. Barcelona, 2013. Entrevista na residência de Ricardo Rodrigo Amar, editor espanhol do grupo RBA.

TOURAINE, Alain. Entrevista. [10 junho2013]. Entrevistador: Maria Cláudia Badan Ribeiro, Paris, 2013. Entrevista na residência do entrevistado.

VÖWE, Rainer [Mensagem pessoal]. Mensagem recebida por <mariaclaudia_badanribeiro@yahoo.com.br> em 07 de maio de 2012 e 09 de fevereiro de 2013. Questões respondidas dos Estados Unidos.

\section{Entrevista com militantes da Rede Solidariedade:}

AMARAL, Maria. Entrevista. [08 maio 2013]. Entrevistador: Maria Cláudia Badan Ribeiro, Champigny, França, 2012. Entrevista na residência da entrevistada.

BARTH, Maurice. Entrevista. [22 julho 2013]. Entrevistador: Maria Cláudia Badan Ribeiro, Paris, 2013. Entrevista realizada no Convento Saint Jacques. Agradeço a Régis Morelon pela ajuda. Padre Barth estava muito doente e foi a última entrevista em vida dada por ele.

BRAIBANT, Sylvie. Entrevista. [17 junho 2013]. Entrevistador: Maria Cláudia Badan Ribeiro, Paris, 2013. Entrevista realizada na sede da TV5 para a América Latina.

DE WANGEN, Sylviane Abou. [02 julho 2013]. Entrevistador: Maria Cláudia Badan Ribeiro, Paris, 2013. Entrevista realizada na Brasserie Café de la Paix.

KAMINSKY, Adolfo. Entrevista. [26 junho 2013]. Entrevistador: Maria Cláudia Badan Ribeiro? Paris, 2013. Entrevista na residência do entrevistado.

PORT, Joyce Blau. Entrevista. [24 junho 2013]. Entrevistador: Maria Cláudia Badan Ribeiro, Paris, 2013. Entrevista no Instituto Curdo de Paris.

\section{Bibliográficas}

ALVES, Márcio Moreira. O Cristo do povo. Rio de Janeiro: Editora Sabiá, 1968.

ARQUIVO EDGARD LEUENROTH (UNICAMP). Acervo Brasil Nunca Mais: processo 634 - a condenação de Pe. Jentel, p. 1219-1223. Campinas: 30 de maio de 1973. 
ARQUIVO EDGARD LEUENROTH (UNICAMP). Acervo Brasil Nunca Mais: processo n 203. Campinas: UNICAMP, 1973.

ASSEFF, Marlon. Retratos do exílio: solidariedade e resistência na fronteira. Santa Cruz do Sul: Edunise, 2009.

AUSSARESSES. Je n'ai pas tout dit : ultimes révélations au service de la France. Entretiens avec Jean-Charles Deniau. Paris: Éditions du Rocher, 2008.

BETTO, Frei. Batismo de fogo. Rio de Janeiro: Bertrand Brasil, 1987.

CALAMAI, Enrico. Niente asilo politico. Milano: Universale Economica Feltrinelli, 2006.

CANNABRAVA, Paulo. No olho do furacão: América Latina nos anos 60/70. São Paulo: Cortez, 2003.

CENTRO DE DOCUMENTAÇÃO E MEMÓRIA DA UNESP (CEDEM). Front Brésilien d'Information (FBI) n.11, 15 de julho de 1970, p. 5-6.

CHANU, Marie-Dominique. Préface. COSMAO, Vincent. Dossier nouvel ordre mondial: Les chrétiens provoqués par le développement: Paris : Chalet, 1978.

CIMADE. Une histoire de la CIMADE (1939-2009) : parce qu'il n' y a pas d' étrangers sur cette terre. La CIMADE 70 ans, Paris : CIMADE, 2009.

COSTA, Jallès. Christianisme et revolution. Lettre, supplement n.119, 1968, p, 101.

DETREZ, Conrad. L'Herbe à brûler. Paris: Calmann-Lévy, 1978.

DRESSEL, Heinz. Kirche und Flüchtlinge. Das Flüchtlingsprogramm des Ökumenischen Studienwerks Bochum. Augsburg: FDL-VERLAG, 1996.

DURKHEIM, Émile. Da divisão do trabalho social [1893]. $2^{\text {a }}$ ed. São Paulo: Martins Fontes, 1999.

DUTERTRE, Alain. Francisco Jentel: defensor do povo do Araguaia. São Paulo: Edições Paulinas, 1986.

EINAUDI, Jean-Luc. Franc-Tireur. Georges Mattéi, de la Guerre d’Algérie à la guérilla. Paris: Éditions du Sextant, 2004.

ESCRIBANO, Francesca. Descalço sobre a terra vermelha. Campinas-SP: Editora da Unicamp, 2000. 
GALLISSOT, René. Henri Curiel. Le mythe mesuré à l'histoire. Paris: Riveneuve Éditions, 2009.

GAUCHER, Roland. Le Réseau Curiel ou la subversion humanitaire. Paris: Éditions Jean Picollec, 1981.

GINLE-LORINET, Sylvaine. Libérer le Prêtre de l'État Clérical. Échanges et Dialogues (1968-1965). Paris: l'Harmattan, 2008.

GUERIN, Antoine. Dom Helder Câmara (1909-1999), le don de l'amour - L'actualité des profetes. Lettre du Pôle Amérique latine, n. 76, mars. 2009. Disponível em: 〈http://www.eglise.catholique.fr/actualites/dossiers/dossiers-de-2009/dom-helder-camarale-don-de-lamour-temoignage-du-p-antoine-guerin/s Acesso em: 12 dez 2014.

HOUAISS, Antônio. Dicionário eletrônico da língua portuguesa. Rio de Janeiro: Instituto Antônio Houaiss; Editora Objetiva, 2006.

JOSÉ, Emiliano. As asas invisíveis do padre Renzo. São Paulo: Casa Amarela, 2002.

KAMINSKY, Sarah. Adolfo Kaminsky, une vie de faussaire. Paris: Calmann-Lévy, 2009.

LANDRÉ, Sabine. Une femme dans son siècle. Paris: Éditions du Temps Présent, 2011.

MAGALHÃES, Mário. Marighella: o guerrilheiro que incendiou o mundo. São Paulo: Companhia das Letras, 2012,

MARIGHELLA, Carlos. O Brasil será um novo Vietnã. Semanário Front, 3 nov. 1969 (mimeo).

MARIN, Richard. Dom Helder Câmara: les Puissants et Les Pauvres. Paris: Les Éditions de l'Atelier, 1995.

MARX, Karl. A questão judaica. [1844]. Tradução da Editora Moraes. $2^{a}$ ed. São Paulo: Moraes, 1991.

MATTÉl, Georges. Brésil: pouvoir et luttes des classes. Hommes et idées du Tiers-Monde. Cahier 3. Paris: Éditions Cujas, 1966.

MATTÉl, Georges. La Guerre des Gusses. Paris: Balland, 1982.

MIRACAPILLO, Vito. Il Caso Miracapillo: paradigma della tensione tra Stato e Chiesa in Brasile. Bologna: Editrice Missionaria Italiana; Quaderni ASAL. Nuova Serie 21, 1981.

NIEDERGANG, Marcel. Les 20 Amériques Latines, Tome 1 et 2. Paris: Éditions du Seuil, 1969. 
OTERO, Lisandro. Llover sobre mojado. Memorias de un intelectual cubano (1957-1997). México, Planeta, 1999.

PADRE LAGE. O padre do diabo. A Igreja ausente na hora de mudar. São Paulo: EMW, 1988.

PELLETIER, Denis. Economie et humanisme : de l'utopie communautaire au combat pour Le Tiers-Monde 1941-1966. Paris: Les Éditions du Cerf, 1996.

PERRAULT, Gilles. Un homme à part : tome 2. Paris: Bernard Barrault, 1984.

QUADRAT, Samantha Viz. (Org.) Caminhos cruzados: historia e memoria dos exílios latino-americanos no século XX. Rio de Janeiro: Editora FGV, 2011.

PREZIA, Benedito. Caminhando na luta e na esperança. Retrospectiva dos últimos 60 anos da Pastoral Indigenista e 30 anos do Conselho Indigenista (CIMI). São Paulo: Edições Loyola, 2003.

ROBIN, Marie-Monique. Escadrons de la mort, l'école française. Paris: Éditions la Découverte, 2004.

ROGALSKI, Michel; TABET, Jean. Des brigades Internationales aux sans-papiers: crise et avenir de la solidarité internationale. Paris: Le temps des cerises, 1998.

VALET, Paul. Prêtre-Ouvrier: itinéraire d'un ancien jociste. Paris: Karthala, 2008.

WINECOK, Michel. Histoire politique de la revue esprit 1930-1950. Paris: Seuil, 1975.

WEBER, Max. Economia e sociedade: fundamentos da sociologia compreensiva. Tradução de Regis Barbosa e Karen Barbosa. Brasília: UNB, 1999.

ZOLL, Rainer. O que é solidariedade hoje? ljuí: Editora ljuí, 1007. 
Recebido em 25/03/2015 Aprovado em 30/04/2016

Universidade do Estado de Santa Catarina - UDESC Programa de Pós-Graduação em História - PPGH Revista Tempo e Argumento Volume 08 - Número 17 - Ano 2016 tempoeargumento@gmail.com 